\title{
Sivistys on tulevaisuuden työelämätaito
}

\author{
Ammattikorkeakoulun tehtävät on ajateltava uusiksi, sillä \\ viheliäiset globaalit ongelmat vaativat koulutusta uudistumaan, \\ sanovat Vuoden 2019 tiedeartikkelin tekijät.
}

TYÖ- JA ELINKEINOELÄMÄÄ palveleva osaaminen, hankkeet ja innovaatiot - niitä ammattikorkeakouluilta on totuttu odottamaan. Niiden rinnalle pitää tuoda ekososiaalinen sivistys tulevaisuuden työelämätaitona, esittävät koulutustutkijat Hannu L. T. Heikkinen ja Harri Kukkonen.

"Ekososiaalinen sivistys viittaa luonnon ja ihmisen kohtalonyhteyteen. Siihen, että luonnon lisäksi ymmärrämme toisiamme. Ennen kaikkea opimme toimimaan yhdessä ongelmien ratkaisemiseksi", he selventävät.

\section{VIISAUTTA OSAAMISEN RINNALLE}

Aikuiskasvatuksessa julkaisemassaan artikkelissa "Ammattikorkeakoulu toisin ajateltuna - Osaaminen, sivistys ja tiedon intressit" Heikkinen ja Kukkonen nostavat sivistyksen osaamispuheen rinnalle. Lanseeraamaansa ajatusta he kutsuvat laajaksi näkemyksen ammattikorkeakoulusta.

Tutkijat perustelevat ja artikuloivat asiansa niin laadukkaasti, että toimituskunta palkitsi heidät Vuoden 2019 tiedeartikkelista. Keskustelunavaus on rohkea, jopa provosoiva, raati kiittää.

Tulevaisuuden suurista kysymyksistä suurimpia on ekokatastrofin uhka.

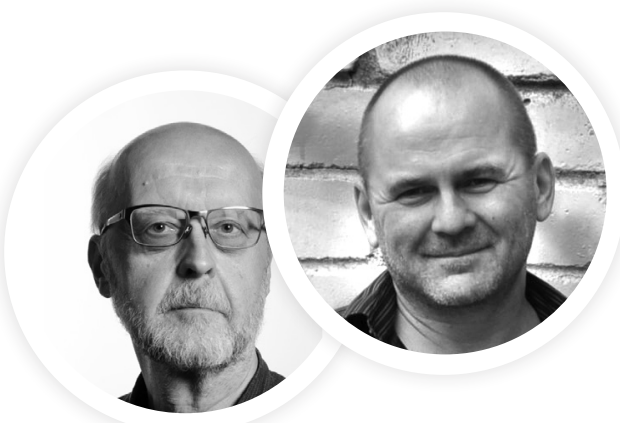

Harri Kukkonen ja Hannu L. T. Heikkinen

"Sen panoksena on koko ihmisten luoman kulttuurin ja elämänmuodon, kenties myös ihmislajin säilyminen planeetallamme. Miksi Homo Sapiens ei ole riittävän viisas muuttaakseen omaa toimintaansa”, Koulutuksen tutkimuslaitoksen professorina työskentelevä Heikkinen kysyy.

\section{MILLAISEEN YHTEISKUNTAAN KOULUTUS VALMENTAA?}

Tutkijat perustavat artikkelinsa antiikin filosofin Aristoteleen klassiseen erotteluun tiedon muodoista 


\section{Raadin perustelut}

Koulutussektori on lähestynyt työelämää varmistaakseen nykyisen yhteiskuntarakenteen säilymistä. Osaaminen on ammattikorkeakoulutuksen tutkimuksen keskiössä, ja sivistys on harvoin nostettu osaamispuheen rinnalle.

Tarve nähdä oppiminen yhteiskunnassa työelämäkyvykkyyttä ja osaajakansalaisuutta avarammin on kuitenkin ilmeinen. Muutoin taannumme toistelemaan vanhaa ja enintään säätämään sitä vähän tehokkaammaksi.

Heikkinen ja Kukkonen lisäävät artikkelillaan ymmärrystä ammattikorkeakoulun sivistystehtävistä yhteiskunnallisissa muutoksissa ja osoittavat, miten sivistystehtäviä on syytä laajentaa. Aiheen kiinnostavuutta lisää se, että ammattikorkeakoulut ja yliopistot tiivistävät yhteistyötään.

Kirjallisuuteen perustuva artikkeli on rakenteeltaan ja käsitteiltään selkeästi etenevä, hyvin kirjoitettu kokonaisuus. Se pohjaa olennaisiin lähteisiin. Selkeät taulukot avaavat tekstiä hyvin.

Tulevaisuuden haasteet ovat ihmisen olemassaolon suuruisia. Sivistys kysyy suuria kysymyksiä, ja niitä kirjoittajat artikkelissaan esittävät. Keskustelulle on nyt kysyntää ja se on viriämässä. Heikkisen ja Kukkosen näkökulma ammattikorkeakoulutukseen on rohkea, jopa provosoiva. ja filosofi Jürgen Habermasin teoriaan tiedon yhteiskunnallisista intresseistä.

Heidän viestinsä on se, että koulutuksen pitää antaa valmiuksia ymmärtää laajasti työelämää, yhteiskuntaa ja maailmaa. Katseen on oltava laaja, perspektiivin pitkä ja tavoitteiden korkealla.

"On tärkeää kysyä, minkälaiseen yhteiskuntaan ja maailmaan opiskelijoita johdatellaan ja millä edellytyksillä. Kaikilla koulutusaloilla on syytä käsitellä esimerkiksi yhteiskunnan ja työelämän polarisaatiota, tasa-arvon ja sosiaalisen oikeudenmukaisuuden kysymyksiä ja ilmastonmuutosta”, tutkijat toteavat.

Laissa mainitaan sivistys ammattikorkeakoulujen opetuksen perustana, sille vain on raivattava tilaa osaamispuheen rinnalle.

\section{TUTKIJAN ÄÄNEN PITÄÄ KUULUA}

Hannu L. T. Heikkinen sanoo usein pohtivansa oman työnsä merkitystä tuleville sukupolville. Meritoituminen akateemisten julkaisujen määrällä tai tutkimusrahasta kilpailemisella tuntuvat varsin vähäpätöisiltä asioilta globaalien haasteiden valossa. Osallistuminen yhteiskunnalliseen keskusteluun sen sijaan on välttämätöntä.

"On paradoksaalista, että yhteiskunnallinen vaikuttaminen on yksi yliopistojen tehtävistä, mutta kaikki tulokset mitataan kuitenkin tutkimuksen tuotoksina eli yhtä kuin julkaisujen määränä”, hän arvostelee.

Tampereen ammatillisen opettajakorkeakoulun yliopettajana työskentelevä Harri Kukkonen on toiveikas sen suhteen, miten artikkelissa lanseerattu näkemys ammattikorkeakoulusta otetaan vastaan. Jo nyt ammattikorkeakouluissa tuotetaan työelämää ja alueen elinkeinorakennetta uudistavaa tutkimustietoa, jossa kannetaan yhteiskunnallista, sosiaalista ja ekologista vastuuta.

"Vallitsevien käytänteiden kriittinen arvioiminen on olennainen osa kaikkien osapuolten toimintaa. Tässä tarvitaan ihmisiä, jotka esittävät välillä hankaliakin kysymyksiä, kyseenalaistavat perususkomuksia ja rohkaisevat myös toisia etsimään vaihtoehtoisia tavoitteita ja tapoja toimia”, hän sanoo. 